ORIGINAL ARTICLE

\title{
Litter decomposition and nutrient release dynamics of leaves and roots of the babassu palm in eastern Amazonia
}

\author{
Ronildson Lima LUZ¹, Márcio Fernandes Alves LEITE, Marcelo Correa ZELARAYÁN², \\ Robert Michael BODDEY ${ }^{3}$, Christoph GEHRING ${ }^{1 *}$ \\ Universidade Estadual do Maranhão (UEMA), Programa de Pós-graduação em Agroecologia, São Luís, Maranhão, Brazil \\ ONG Educação e Meio Ambiente (EMA), Pirapemas, Maranhão, Brazil \\ 3 Embrapa Agrobiologia, Seropédica, Rio de Janeiro, Brazil \\ * Corresponding author: christophgehring@yahoo.com.br; (D) https://orcid.org/0000-0002-1964-4397
}

\begin{abstract}
The ruderal babassu palm (Attalea speciosa) is expanding on large areas of degraded Amazon landscapes. Decomposition of leaves and roots is in the center of plant:soil interactions. We evaluated decomposition and nutrient concentrations of leaves and fine roots of babassu in comparison with two exotic reference species, Acacia mangium (slow degradability) and Leucaena leucocephala (fast degradability), in a 138-day litterbag assay carried out in secondary forest stands of different age and babassu abundance. We chose 4-mm over 2-mm mesh litterbags based on a pilot study. Babassu leaves degraded slower than leaves of $A$. mangium and L. leucocephala, and also had lower nitrogen, phosphorus and calcium concentrations in all stages of decomposition. By contrast, potassium concentrations in babassu leaves were higher than in both reference species at 0 and 50 days. Roots of all three species decomposed slower than leaves. Compared to the leaves, both biomass loss and nutrient concentrations differed less between babassu and reference-species roots, except for lower nitrogen concentration in babassu roots. Leaf-litter decomposition of all three species was significantly faster in old than in young secondary forest, suggesting an acceleration of decomposition along succession. Babassu leaves decomposed faster in old babassu-dominated than nondominated secondary forest, pointing to the existence of specialized decomposer communities in babassu-dominated stands.
\end{abstract}

KEYWORDS: Attalea speciosa, litter bag, nutrient concentrations, ruderal palm, secondary succession, soil organic matter

\section{Decomposição de serrapilheira e dinâmica de nutrientes de folhas e raízes da palmeira babaçu na periferia leste da Amazônia}

\section{RESUMO}

A palmeira ruderal babaçu (Attalea speciosa) se expande em grandes áreas da Amazônia já desmatada e degradada. A decomposição é chave na dinâmica sucessional e nas interaçôes planta:solo. Avaliamos decomposição e concentração de nutrientes de folhas e raízes finas de babaçu e de duas espécies exóticas de referência, Acacia mangium (decomposição lenta) e Leucaena leucocephala (decomposição rápida), em capoeiras de diferente idade e grau de dominância de babaçu usando litterbags durante 138 dias. Usamos litterbags com malha de $4 \mathrm{~mm}$ em vez de $2 \mathrm{~mm}$, com base em um estudo-piloto. As folhas de babaçu se decompuseram mais lentamente que as de $A$. mangium e $L$. leucocephala, e apresentaram concentraçôes mais baixas de nitrogênio, fósforo e cálcio em todos os estágios de decomposição. Em contraste, a concentração de potássio em folhas de babaçu foi mais alta que nas espécies de referência aos 0 e 50 dias. Raízes se decompuseram mais lentamente que folhas nas três espécies. Tanto a perda de massa, como a concentração de nutrientes diferiram menos entre as raízes que entre as folhas de babaçu e as espécies de referência, exceto a concentração de nitrogênio nas raízes de babaçu. A decomposição foliar das três espécies foi significantemente mais rápida em capoeira velha que em capoeira jovem, sugerindo uma aceleração da decomposição ao longo dos estágios sucessionais. A decomposição foliar do babaçu foi mais rápida em capoeira velha com alta dominância de babaçu que em capoeira velha com baixa dominância, apontando para a existência de comunidades especializadas de decompositores em áreas dominadas por babaçu.

PALAVRAS-CHAVE: Attalea speciosa, liberação de nutrientes, matéria orgânica do solo, palmeira ruderal, sucessão secundária 


\section{INTRODUCTION}

In the humid tropics, including the Amazon, repeated cycles of slash-and-burn agriculture with shortening fallow periods promote the persistence and dominance of aggressive ruderal plants (Loehle 1988; Chai et al. 2016; Schweiger $e t$ al. 2017). These outcompete other plants and possess the capability to grow in low-resource, frequently burned degraded environments following agricultural land abandonment (Chai et al. 2016). Typical features are earlier reproduction and great dispersal capacity (Brooks et al. 2004), and the production of allelopathic compounds (Souto et al. 2001). They shape soil chemical properties in their surroundings to their favor (Ehrenfeld 2003), governing nutrient cycling (Blank 2008) and microbial communities (Kourtev et al. 2003). In the longterm, this can favor more specialized decomposer communities capable of accessing more recalcitrant materials (Ayres et al. 2009). The existence of such a 'home-field advantage' is primarily driven by differential litter quality (Veen et al. 2015). Home-field advantages and other forms of positive plant:soil feedbacks are often key for the ecological success of megadominant species (Kulmatski et al. 2008).

In wide parts of deforested former Amazonia, especially throughout the deforestation arc of the eastern and southern peripheries (Teixeira and da Graça Carvalho 2007), unsustainable repeated slash-and-burning and frequent pasture fires favor dominance of the ruderal babassu palm, Attalea speciosa Mart. (Acecaceae). Although babassu occurs in low abundance in mature rainforests, its dominance increases dramatically after repeated burns and reduced fallow periods, in some cases forming near monospecific stands, the so called 'babassuais' (May et al. 1985). Few studies have so far attempted to explore possible pathways for the outstanding ecological success of babassu, with the notable exception of the studies by Germer et al. (2012) on preferential stemflow-dynamics of rainwater combined with high potassium concentrations in the stemflow of large-leaved juvenile babassu palms, and Rodrigues et al. (2015) on babassu-impacts on soil microbial biomass. Babassu may also influence its surroundings via its fine root system, as fine-root tissue chemistry is an important driver of ecosystem carbon and nutrient dynamics (Goebel 2011). Babassu impacts may be stronger belowground than aboveground, as indicated by higher babassu biomass shares in fine roots than in aboveground vegetation shares (Sousa $e t$ al. 2016). Babassu roots could be relevant for carbon stocks in degraded soils subjected to repeated slash-and-burn and short fallows.

This study compared the dynamics of babassu leaf and fine-root litter decomposition and nutrient release in comparison with two exotic and widely-used legume reference species: one with low tissue quality, Acacia mangium Willd and one with high tissue quality, Leucaena leucocephala (LAm.) DE WIT (Tian et al. 1992), both very common in tropical agroforestry systems (Sanginga et al. 1995; Dubeux et al. 2017). We also evaluated the effects of successional age of forest stands and of babassu dominance on babassu leaf and fine-root decomposition. We hypothesized that babassu litter decomposition dynamics could be one of the pathways for the ecological success of this ruderal palm, via creation of home-field advantages or other pathways of positive plant:soil feedbacks between babassu and its surroundings.

\section{MATERIAL AND METHODS}

\section{Study region and sites}

The field study was conducted at four sites in the eastern periphery of Amazonia, on São Luis Island, Maranhão state, Brazil (2。1'S, $\left.4^{\circ} 16^{\prime} \mathrm{W}\right)$. The climate in the area is classified as sub-humid equatorial $A w$ according to the Köppen system, with about $2000 \mathrm{~mm}$ annual rainfall largely concentrated in a 7-month rainy season and 5 months of hydric deficit (Alvares et al. 2013). The soil is sandy $(85.4 \%$ sand, $4.4 \%$ silt and $10.2 \%$ clay accross all four sites and pooled $0-5$ and 5-15-cm horizons) and classified as Ultisol, Typic Paleustult (USDA 2010).

We established one $50 \times 50$-m (excluding large borderzones) plot in each of two 3-year-old and two 20-year-old secondary-forest sites (young and old sites from here on). In each age class, one site had high, and the other low babassu dominance (high-dominance and low-dominance sites from here on). Apart from the experimental factors, we sought to standardize other environmental factors, such that sameaged sites were adjacent to each other and, to the best of our knowledge, had the same use history, and were visually within the same soil catena. All sites were level $\left(<2^{\circ}\right.$ inclination). Total aboveground biomass was $47.5 \pm 18.9 \mathrm{Mg} \mathrm{ha}^{-1}$ in the two young sites, and $60.4 \pm 17.6 \mathrm{Mg} \mathrm{ha}^{-1}$ in the two old sites, with a babassu-share in total aboveground biomass of $74.4 \pm$ $8.1 \%$ in the high-dominance sites, and $21.2 \pm 6.7 \%$ in the low-dominance sites. Topsoil $(0-5 \mathrm{~cm})$ texture was $85.8 \% \pm$ 4.1 sandy over all sites, with no significant difference among sites, and with acid $\mathrm{pH}(4.54 \pm 0.1)$ and low availability of phosphorus, $\mathrm{P}\left(5.7 \pm 0.6 \mathrm{~g} \mathrm{~kg}^{-1}\right)$, potassium, $\mathrm{K}(0.75 \pm 0.06$ $\left.\mathrm{g} \mathrm{kg}^{-1}\right)$ and calcium, Ca $\left(20.62 \pm 1.82 \mathrm{~g} \mathrm{~kg}^{-1}\right)$. P availability was higher in the old sites, and $\mathrm{K}$ availability was higher in the young sites (unpublished data).

\section{Plant tissue}

We chose Acacia mangium and Leucaena leucocephala as the two reference species for comparison with babassu foliar and root decomposition dynamics because they represent the two ends of 'plant tissue quality' (Tian et al. 1992). Leucaena leucocephala has high foliar nitrogen concentration, paired with low lignin (5.4\%) and polyphenol (6.9\%), associated with a very high decomposition rate (Jama and Nair 1996). Acacia mangium has high lignin concentration (43.6\%) in the 
leaves, associated with low decomposition rates (O'Connell and Sankaran 1997; Rahman and Moitur 2012; Saad et al. 2012).

Plant tissue was used in a litterbag experiment and was standardized for the three species. Each litterbag contained 30$50 \mathrm{~g}$ (dry weight basis) of a mixture of foliar material (sun and shade leaves, excluding senescent leaves, and leaves with visual symptoms of insect, bacterial or fungal infestation) or root material (fine live roots of $<2 \mathrm{~mm}$ ). We sampled root material from end-branches (Pagès et al. 2004). As babassu roots tended to be somewhat thicker than reference-tree roots, babassu fine roots also included some larger $(<3 \mathrm{~mm})$ root segments. We excluded mid-sized and coarse roots (predominantly stiff, lignified and long-lived, and therefore with low root turnover), and the more ephermal structures known as 'root hairs' $(<1$ mm) (Goebel et al. 2011; Mccormack et al. 2015), as these were washed away with root processing. We washed roots for removal of soil and debris and retained subsamples for dry weight determination. Washed fresh roots were immediately (same day) buried as described below. All plant material was obtained from two to four adult plants of each species on São Luis Island.

\section{Litterbag experiment}

The decomposition trial was carried out over 138 days during the rainy season. Decomposition was measured via litterbag retrieval at each of five time points $(25,50,78,108$ and 138 days). We used 4-mm mesh nylon litterbags based on preliminary tests on different mesh sizes (unpublished data). In each of the four study plots, we placed four litterbag clusters: three containing litterbags of the three species and one containing exclusively babassu litterbags. In each cluster, there were five pairs of leaf and root litterbags per species. At each time-point, one pair per species was removed from each cluster for analysis, totaling 16 pairs per time point for babassu (four pairs per plot) and 12 pairs for each reference species (three per plot). The maximum distance between litterbags of a cluster was $<2 \mathrm{~m}$ (providing similar microclimatic conditions) and minimum distance between clusters within a site was $>20 \mathrm{~m}$. Leaf litterbags were placed on the soil surface after removal of the existing litter-layer. Rroot litterbags were placed within $5-10 \mathrm{~cm}$ depth and carefully covered with the previously removed $0-5 \mathrm{~cm}$ topsoil and O-horizon, in order to guarantee access of the root decomposer communities. Upon retrieval of L. leucocephala leaf litterbags we also checked the surroundings for small leaflets which might had fallen out of the litterbags.

\section{Sample processing and analytics}

At each time-point, litterbags were removed and subsequently cleaned of other debris with deionized water and dried to constant weight at $60^{\circ} \mathrm{C}$, weighed and ground. We conducted chemical analyses of leaf and root samples of the source material at the beginning of the experiment (day zero, single composite sample) and from litterbags at 50 and 138 days. We determined carbon (C) and nitrogen (N) concentrations in an autoanalyzer (Carlo Erba EA 1108, MAT, Bremen, Germany) at the laboratory of Dr. Robert M. Boddey (EMBRAPA Agrobiology, Rio de Janeiro, Brazil). The concentration of the remaining nutrients $[\mathrm{P}, \mathrm{K}, \mathrm{Ca}$, $\mathrm{Mg}$ and $\mathrm{Zn}$ ] was determined by complete extraction with $\mathrm{HClO}_{4}+\mathrm{HNO}_{3}$, following standard procedures described in IAC (2001) and subsequent measurement via inductive ultraviolet plasma spectrometry ICP-OES (ICP-720 ES, Agilent Technologies, CA, USA) in the soil chemistry laboratory of Maranhão State University (UEMA), São Luis, Brazil.

\section{Data processing and statistics}

We analyzed leaves and roots separately. Dry mass reduction via decomposition was determined as the percentage of remaining biomass at each time-point relative to the original biomass at day zero. Distribution of normality was evaluated for all variables at each time-point using both the Kolmogorov Smirnov and Lilliefors's tests. Homogeneity of variance of all variables along time was checked via the Brown-Forsythe test. As not all variables complied with requierements for parametric analysis at all time-points, we compared decomposition at each time-point using nontransformed data with the non-parametric Dunn's test. Values $>1.96^{*}$ SE were discarded from the dataset as outliers (total of 18 outliers from six variables at some time-point) (Cousineau and Chartier 2010).

We evaluated the effects of stand age and babassu dominance on leaf and root decomposition rates for each species via ANOVA model fitting, with three levels of hierarquical nesting (stand age $>$ babassu dominance $>$ litter origin) along time, with four (babassu) or three (reference species) replications per factor. Additionally, we conducted t-tests to evaluate differences in remaining biomass between stand age and babassu dominance levels at each point in time. For each species, we fitted first-order exponential models to describe leaf and root decomposition in different treatments, following the best-model fitting based on the AIC criterion.

We explored species-specific changes in mass and nutrient concentrations along time with the Marcus-test (Marcus 1976), a one-way ANOVA with decomposition time aligned in an ordinate scale. The non-parametric Marcus test is robust against violations against normality and homogeneity of variance (Bretz et al. 2016). We corrected the differing number of replicates in nutrient concentrations among species following procedures described in Hothorn et al. (2008).

Multiple comparisons via Marcus test and hierarquicaly nested ANOVA were performed in the $\mathrm{R}$ environment using the package multicomp and lme4. All other tests and exploratory analyses were done using Statistica 8.0 software. 


\section{RESULTS}

\section{Decomposition constants}

First order exponential models fitted to data of each species showed that decomposition coefficients were 325\% steeper in leaves of $A$. mangium and $587 \%$ steeper in leaves of $L$. leucocephala than in babassu leaves over all study sites. Leaf decomposition coefficients of all three species were steeper in old than in young forest. Babassu foliar decomposition coefficient was $250 \%$ steeper in the old high-dominance site than in the old low-dominance babassu site, suggesting faster decomposition in older babassu-dominated secondary forests (Table 1).

Between-species differences were much smaller for roots than for leaves. Decomposition of babassu roots was similar to A.mangium roots. Contrary to babassu leaves, neither stand age nor babassu dominance affected babassu root decomposition.

\section{Biomass loss}

As expected, L. leucocephala leaves decomposed significantly faster than those of $A$. mangium leaves. Babassu leaf decomposition was slower than that of $A$. mangium (Figure 1a), significantly so in advanced stages of decomposition, with $68.9 \%$ of original biomass remaining after 108 days and 63.2\% after 138 days, establishing babassu leaves as a very low-quality tissue.

Overall the root decomposition rate (across species, treatments and time) was $57.3 \%$ slower than that of leaves, and root biomass did not decrease below $60 \%$ in most litterbags after 138 days (Figure 1b). Contrary to the leaves, babassu roots decomposed faster than those of both reference species, significantly so in the first 50 days.

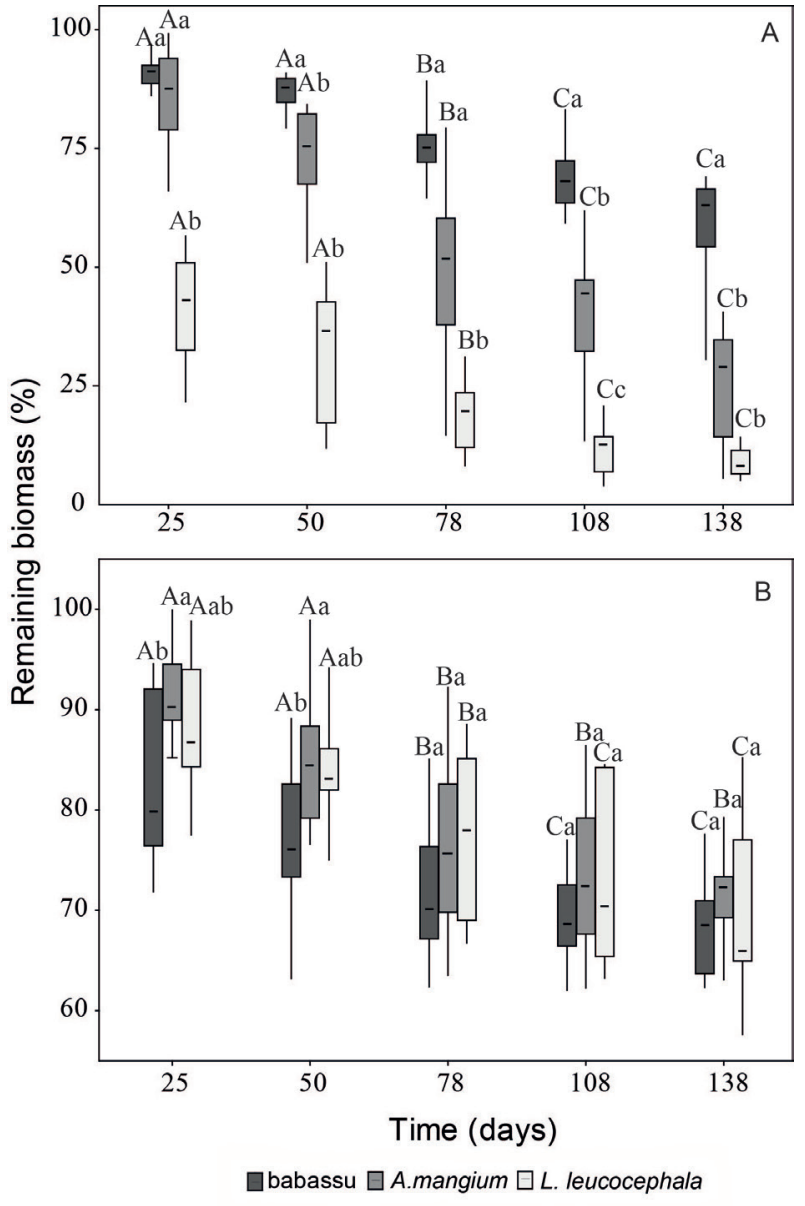

Figure 1. Biomass loss over time of experimentally decomposing leaves (A) and roots (B) of babassu (Attalea speciosa), Acacia mangium and Leucaena leucocephala (pooled data from all sites). Box-plots show the medians, 25-75 quartiles and whiskers the data-range. Upper-case letters indicate statistical differences in biomass loss within each species along time according to a Marcus test. Lower-case letters indicate statistical differences between species according to Kruskall-Wallis test.

Table 1. Model adjustment of the effect of babassu density (high and low dominance) and age of secondary forest sites (old and young) on the decomposition of

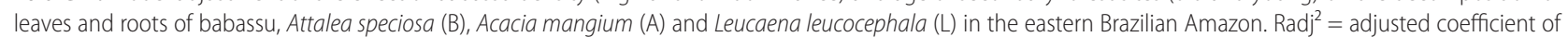
determination; $\mathrm{AIC}=$ Akaike Information Criterion (lower value indicates best-fit equations).

\begin{tabular}{|c|c|c|c|c|c|c|c|c|c|}
\hline \multirow{2}{*}{ Stand age } & \multirow{2}{*}{$\begin{array}{c}\text { Babassu } \\
\text { dominance }\end{array}$} & \multirow{2}{*}{ Species } & \multirow{2}{*}{$N$} & \multicolumn{3}{|c|}{ Leaves } & \multicolumn{3}{|c|}{ Roots } \\
\hline & & & & Equation & Radj $^{2}$ & AlC & Equation & $\operatorname{Radj}^{2}$ & AIC \\
\hline \multirow{6}{*}{ Old } & \multirow{3}{*}{ High } & B & 19 & $y-y^{0}=e^{-0.005 t}$ & 0.64 & -5.33 & $y-y^{0}=e^{-0.002 t}$ & 0.70 & -55.44 \\
\hline & & A & 15 & $y-y 0=e^{-0.01 t}$ & 0.72 & 6.91 & $y-y^{0}=e^{-0.002 t}$ & 0.66 & -25.65 \\
\hline & & L & 15 & $y-y 0=e^{-0.02 t}$ & 0.87 & 7.79 & $y-y^{0}=e^{-0.003 t}$ & 0.89 & -44.32 \\
\hline & \multirow{3}{*}{ Low } & B & 19 & $y-y 0=e^{-0.002 t}$ & 0.58 & -33.24 & $y-y^{0}=e^{-0.002 t}$ & 0.64 & -45.95 \\
\hline & & A & 15 & $y-y 0=e^{-0.01 t}$ & 0.57 & 29.30 & $y-y^{0}=e^{-0.001 t}$ & 0.58 & -34.28 \\
\hline & & L & 14 & $y-y 0=e^{-0.015 t}$ & 0.75 & 19.11 & $y-y^{0}=e^{-0.003 t}$ & 0.85 & -39.38 \\
\hline \multirow{6}{*}{ Young } & \multirow{3}{*}{ High } & B & 20 & $y-y 0=e^{-0.003 t}$ & 0.82 & -43.20 & $y-y^{0}=e^{-0.002 t}$ & 0.58 & -42.47 \\
\hline & & A & 14 & $y-y 0=e^{-0.008 t}$ & 0.77 & -1.90 & $y-y^{0}=e^{-0.002 t}$ & 0.76 & -42.14 \\
\hline & & L & 15 & $y-y 0=e^{-0.016 t}$ & 0.71 & 24.25 & $y-y^{0}=e^{-0.0008 t}$ & 0.25 & -36.89 \\
\hline & \multirow{3}{*}{ Low } & B & 19 & $y-y 0=e^{-0.003 t}$ & 0.78 & -43.85 & $y-y^{0}=e^{-0.002 t}$ & 0.79 & -58.08 \\
\hline & & A & 15 & $y-y 0=e^{-0.01 t}$ & 0.62 & 15.47 & $y-y^{0}=e^{-0.002 t}$ & 0.52 & -25.13 \\
\hline & & L & 15 & $y-y 0=e^{-0.02 t}$ & 0.79 & 17.18 & $y-y^{0}=e^{-0.002 t}$ & 0.71 & -31.08 \\
\hline
\end{tabular}




\section{Effects of stand age and babassu dominance}

Neither stand age nor babassu dominance affected babassu leaf decomposition, while babassu root decomposition was significantly affected by both factors, with significant interactions that point to an acceleration of babassu root decomposition along succession and with babassu dominance (Table 2).

Remaining leaf biomass after 138 days was significantly higher in babassu than in L. leucocephala (all treatments) and A. mangium (in three out of four treatments) (Figure 2). Stand age significantly affected leaf-mass loss of all three species, and babassu dominance significantly affected babassu leaf-mass loss.
Root-mass loss was slower than in leaves and speciesspecific differences were likewise smaller. Contrary to the leaves, babassu root decomposition was significantly faster than in reference species at some stages of the monitoring period in all four treatments (Figure 3).

\section{Variation in carbon and nutrient concentration}

Compared to both reference species, babassu leaves had the lowest $\mathrm{N}, \mathrm{P}$ and $\mathrm{Ca}$ concentrations at all decomposition stages (Table 3). In contrast, initial foliar $\mathrm{K}$ concentrations at day zero and at 50 days were higher in babassu than in both reference species.

C concentrations in babassu leaves declined with decomposition and laid between those of L. leucocephala and
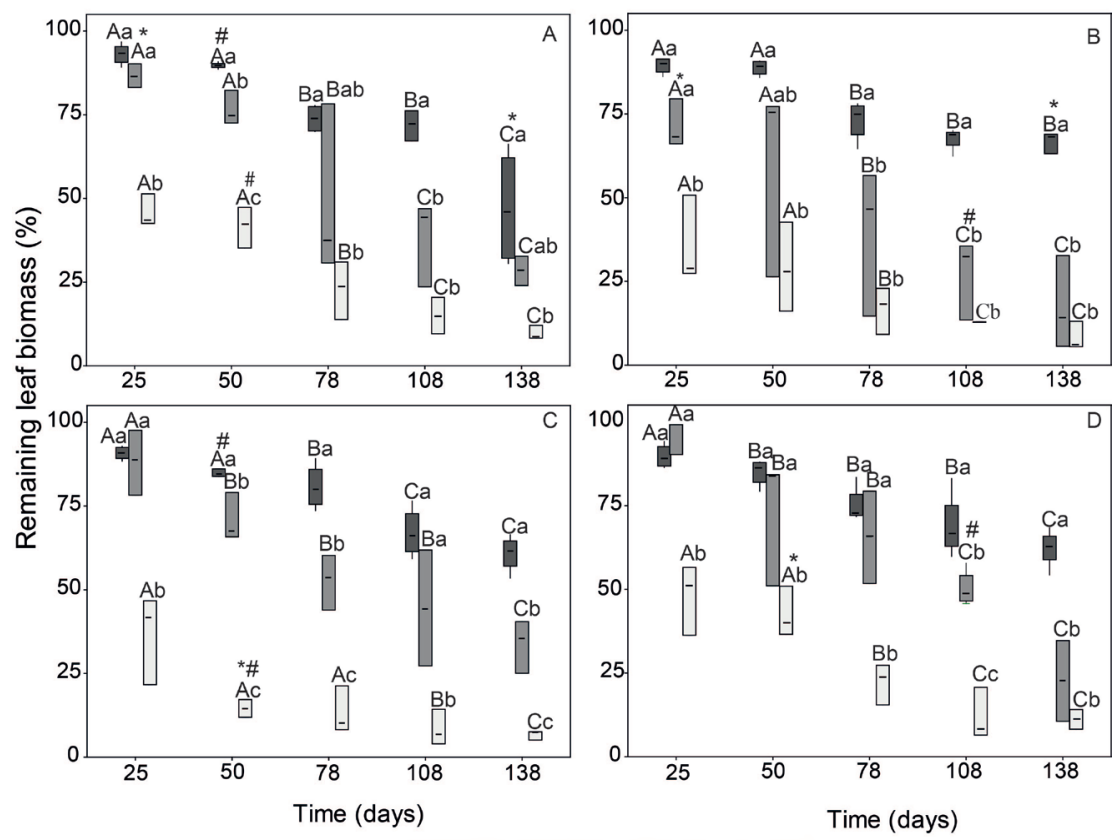

$\square$ babassu $\square$ A.mangium $\square$ L. leucocephala

Figure 2. Leaf biomass loss over time of Attalea speciosa (babassu), Acacia mangium and Leucaena leucocephala in secondary forests of contrasting stand age and degree of babassu dominance. Box-plots show the medians, 25-75 quartiles and whiskers the data-range. A - old secondary forest with high babassu dominance; B - old secondary forest with low babassu dominance; C - young secondary forest with high babassu dominance; D - young secondary forest with low babassu dominance. Upper-case letters indicate statistical differences in biomass loss within each species over time according to a Marcus test. Lower-case letters indicate statistical differences between species within each sampling date according to a non-parametric Dunn's test. Hashtag signs indicate significant differences between stand ages within species and sampling day, and asterisks indicate significant differences between babassu dominance levels within species and sampling day, both according to Mann-Whitney U-tests.

Table 2. Results of hierarchical nested ANOVA for the effect of age and babassu dominance of secondary forest stands over time on the decomposition of leaves and roots of babassu, Attalea speciosa in the eastern Brazilian Amazon (MS = Mean square; $F \mathrm{C}=\mathrm{F}$ test; $\mathrm{Pr}=\mathrm{p}$ test).

\begin{tabular}{|c|c|c|c|c|c|c|}
\hline \multirow{2}{*}{ Factor } & \multicolumn{3}{|c|}{ Leaves } & \multicolumn{3}{|c|}{ Roots } \\
\hline & MS & Fc & $\operatorname{Pr}(>\mathrm{Fc})$ & MS & FC & $\operatorname{Pr}(>\mathrm{Fc})$ \\
\hline Age & 0.77 & 0.02 & 0.89 & 1564.05 & 112.45 & $4.188 \mathrm{e}-15^{* * *}$ \\
\hline Dominance (age) & 28.43 & 0.63 & 0.54 & 176.20 & 12.34 & $3.53 e-05^{* * *}$ \\
\hline Time (dominance, age) & 704.13 & 15.59 & $2.846 \mathrm{e}-15^{* * *}$ & 176.20 & 12.67 & $2.41 \mathrm{e}-13^{* * *}$ \\
\hline Error & 45.16 & - & - & 13.91 & - & - \\
\hline
\end{tabular}




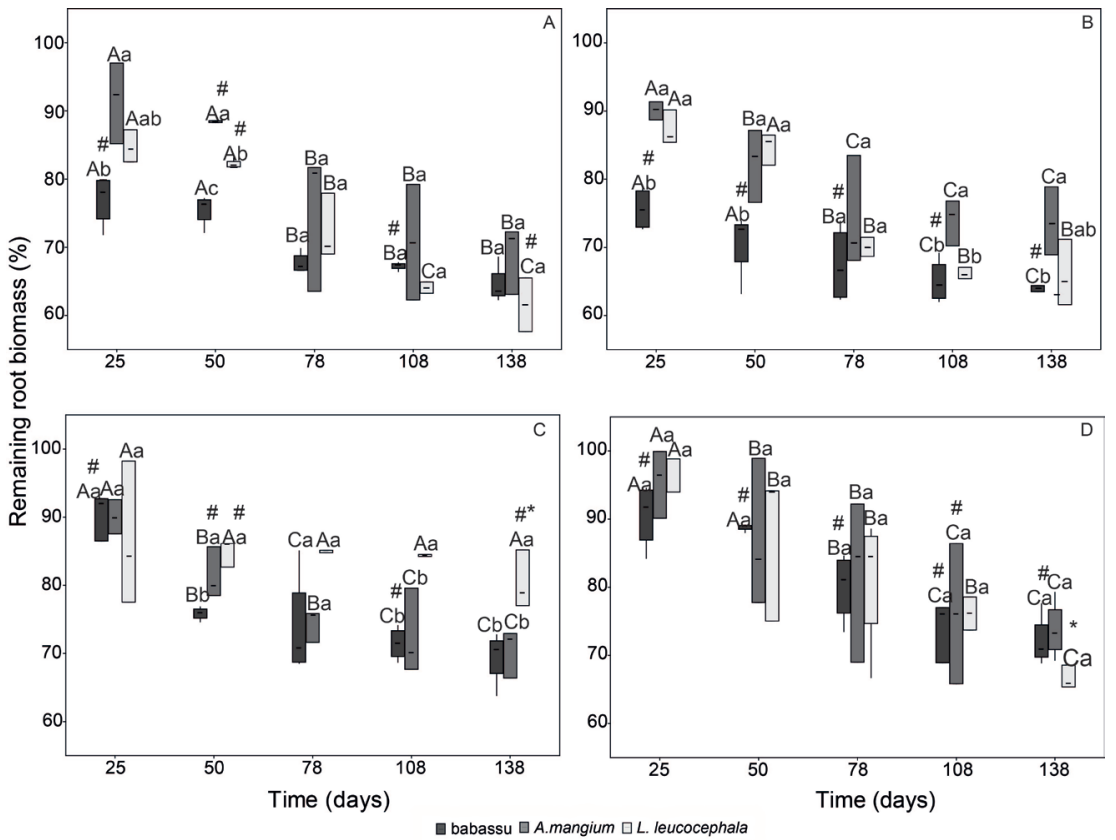

Figure 3. Fine-root mass loss over time of Attalea speciosa (babassu), Acacia mangium and Leucaena leucocephala in secondary forests of contrasting stand age and degrees of babassu dominance. Box-plots show the median, 25-75 quartiles and whiskers the data-range. A - old secondary forest with high babassu dominance; B - old secondary forest with low babassu dominance; C - young secondary forest with high babassu dominance; D - young secondary forest with low babassu dominance. Upper-case letters indicate statistical differences in biomass loss within each species over time according to a Marcus test. Lower-case letters indicate statistical differences among species within each sampling date according to a non-parametric Dunn's test. Hash signs indicate differences between stand ages within the same day and plant, and asterisks indicate effects of babassu dominance within the same day and plant, both according to Mann-Whitney U-tests.

Table 3. Carbon and nutrient concentrations in leaves and fine roots of Attalea speciosa (babassu), Acacia mangium and Leucaena leucocephala (medians and interquartile ranges). Different capital letters indicate significant differences within species among time-points (0,50 and 138 days) according to the Marcus test. Different lower-case letters indicate significant differences among species within the same time-point according to Dunn's test.

\begin{tabular}{|c|c|c|c|c|c|c|c|c|c|}
\hline & \multicolumn{9}{|c|}{ Leaves } \\
\hline & \multicolumn{3}{|c|}{ A. speciosa $(n=33)$} & \multicolumn{3}{|c|}{ A. mangium $(n=21)$} & \multicolumn{3}{|c|}{ L. leucocephala $(\mathrm{n}=27)$} \\
\hline & 0 & 50 & 138 & 0 & 50 & 138 & 0 & 50 & 138 \\
\hline$C(\%)$ & 66.17 & $\begin{array}{c}53.98 \\
(1.68) \mathrm{Aab}\end{array}$ & $\begin{array}{c}47.98 \\
(11.08) \text { Bab }\end{array}$ & 62.53 & $\begin{array}{c}57.44 \\
(8.69) \mathrm{Aa}\end{array}$ & $\begin{array}{c}51.39 \\
(17.75) \mathrm{Aa}\end{array}$ & 45.75 & $\begin{array}{c}44.56 \\
(12.65) \mathrm{Ab}\end{array}$ & $\begin{array}{c}36.18 \\
(17.83) \mathrm{Ab}\end{array}$ \\
\hline $\mathrm{N}(\%)$ & 1.30 & $\begin{array}{c}1.48 \\
(0.20) \mathrm{Ab}\end{array}$ & $\begin{array}{c}1.22 \\
(0.27) \mathrm{Bb}\end{array}$ & 2.19 & $\begin{array}{c}2.67 \\
(0.84) \mathrm{Aa}\end{array}$ & $\begin{array}{c}2.11 \\
(0.87) \mathrm{Aa}\end{array}$ & 2.73 & $\begin{array}{c}2.27 \\
(1.35) \mathrm{Aa}\end{array}$ & $\begin{array}{c}0.38 \\
(0.30) \mathrm{BC}\end{array}$ \\
\hline$P\left(\mathrm{mg} \mathrm{kg}^{-1}\right)$ & 2.13 & $\begin{array}{c}2.08 \\
(0.14) \mathrm{Ab}\end{array}$ & $\begin{array}{c}1.94 \\
(0.25) \mathrm{Ab}\end{array}$ & 2.56 & $\begin{array}{c}2.39 \\
(0.11) \mathrm{Aa}\end{array}$ & $\begin{array}{c}2.60 \\
(0.97) \mathrm{Aa}\end{array}$ & 3.23 & $\begin{array}{c}2.64 \\
(1.34) \mathrm{Aa}\end{array}$ & $\begin{array}{c}1.70 \\
(0.79) \mathrm{Bb}\end{array}$ \\
\hline $\mathrm{K}\left(\mathrm{mg} \mathrm{kg}^{-1}\right)$ & 7.07 & $\begin{array}{c}1.62 \\
(0.32) \mathrm{Aa}\end{array}$ & $\begin{array}{c}0.79 \\
(0.10) \mathrm{Ba}\end{array}$ & 4.37 & $\begin{array}{c}1.14 \\
(0.37) \mathrm{Ab}\end{array}$ & $\begin{array}{c}0.75 \\
(0.22) \mathrm{Ba}\end{array}$ & 6.28 & $\begin{array}{c}0.94 \\
(0.43) \mathrm{Ab}\end{array}$ & $\begin{array}{c}0.65 \\
(0.35) \mathrm{Ba}\end{array}$ \\
\hline $\mathrm{Ca}\left(\mathrm{mg} \mathrm{kg}^{-1}\right)$ & 1.06 & $\begin{array}{c}0.90 \\
(0.13) \mathrm{Ab}\end{array}$ & $\begin{array}{c}0.63 \\
(0.31) \mathrm{Bb}\end{array}$ & 4.88 & $\begin{array}{c}4.06 \\
(1.34) \mathrm{Aa}\end{array}$ & $\begin{array}{c}2.57 \\
(1.24) \mathrm{Aa}\end{array}$ & 4.84 & $\begin{array}{c}4.25 \\
(2.37) \mathrm{Aa}\end{array}$ & $\begin{array}{c}2.25 \\
(1.30) \mathrm{Ba}\end{array}$ \\
\hline $\operatorname{Mg}\left(\mathrm{mg} \mathrm{kg}^{-1}\right)$ & 1.16 & $\begin{array}{c}0.97 \\
(0.10) \mathrm{Aa}\end{array}$ & $\begin{array}{c}0.86 \\
(0.35) \mathrm{Ba}\end{array}$ & 0.97 & $\begin{array}{c}0.97 \\
(0.02) \mathrm{Aa}\end{array}$ & $\begin{array}{c}0.95 \\
(0.60) \mathrm{Aa}\end{array}$ & 2.12 & $\begin{array}{c}1.73 \\
(0.68) \mathrm{Aa}\end{array}$ & $\begin{array}{c}0.83 \\
(0.43) \mathrm{Ba}\end{array}$ \\
\hline $\mathrm{Zn}\left(\mathrm{mg} \mathrm{kg}^{-1}\right)$ & 1.45 & $\begin{array}{c}1.37 \\
(0.09) \mathrm{Aa}\end{array}$ & $\begin{array}{c}1.27 \\
(0.39) \mathrm{Ab}\end{array}$ & 1.40 & $\begin{array}{c}1.42 \\
(0.10) \mathrm{Aa}\end{array}$ & $\begin{array}{c}1.62 \\
(0.85) \mathrm{Aa}\end{array}$ & 1.43 & $\begin{array}{c}1.39 \\
(0.54) \mathrm{Aa}\end{array}$ & $\begin{array}{c}1.20 \\
(0.47) \mathrm{Ab}\end{array}$ \\
\hline$C: N$ & 50.72 & $\begin{array}{c}36.63(4.13) \\
\mathrm{Aa}\end{array}$ & $\begin{array}{c}40.03 \\
(6.74) \mathrm{Aab}\end{array}$ & 28.50 & $\begin{array}{c}19.75 \\
(2.68) \mathrm{Ba}\end{array}$ & $\begin{array}{c}24.24 \\
(2.21) \mathrm{Ab}\end{array}$ & 16.76 & $\begin{array}{c}18.34 \mathrm{~B} \\
(5.06) \mathrm{Ba}\end{array}$ & $\begin{array}{c}101.69 \\
(28.65) \mathrm{Aa}\end{array}$ \\
\hline$C: P$ & 405.99 & $\begin{array}{c}376.31 \\
(41.97) \mathrm{Ab}\end{array}$ & $\begin{array}{c}310.67 \\
(37.34) \mathrm{Ba}\end{array}$ & 536.74 & $\begin{array}{c}619.94 \\
(160.01) \mathrm{Aa}\end{array}$ & $\begin{array}{c}482.21 \\
(139.02) \mathrm{Ba}\end{array}$ & 387.05 & $\begin{array}{c}420.52 \\
(179.44) \mathrm{Ab}\end{array}$ & $\begin{array}{c}69.49 \\
(49.64) \mathrm{Ba}\end{array}$ \\
\hline
\end{tabular}


Table 3. Continued.

\begin{tabular}{|c|c|c|c|c|c|c|c|c|c|}
\hline & \multicolumn{9}{|c|}{ Roots } \\
\hline & \multicolumn{3}{|c|}{ A. speciosa $(n=35)$} & \multicolumn{3}{|c|}{ A. mangium $(n=30)$} & \multicolumn{3}{|c|}{ L. leucocephala $(n=29)$} \\
\hline & 0 & 50 & 138 & 0 & 50 & 138 & 0 & 50 & 138 \\
\hline C (\%) & 62.08 & $\begin{array}{c}55.33 \\
(3.76) \mathrm{Aa}\end{array}$ & $\begin{array}{c}49.68 \\
(6.40) \mathrm{Ba}\end{array}$ & 60.49 & $\begin{array}{c}48.89 \\
(10.16) \mathrm{Aa}\end{array}$ & $\begin{array}{c}49.40 \\
(7.09) \mathrm{Aa}\end{array}$ & 58.44 & $\begin{array}{c}52.11 \\
(6.63) \mathrm{Aa}\end{array}$ & $\begin{array}{c}47.75 \\
(6.66) \mathrm{Ba}\end{array}$ \\
\hline N (\%) & 0.49 & $\begin{array}{c}0.46 \\
(0.09) \mathrm{Ab}\end{array}$ & $\begin{array}{c}0.44 \\
(0.15) \mathrm{Ac}\end{array}$ & 0.94 & $\begin{array}{c}1.23 \\
(0.15) \mathrm{Aa}\end{array}$ & $\begin{array}{c}0.93 \\
(0.08) \mathrm{Aa}\end{array}$ & 1.24 & $\begin{array}{c}1.26 \\
(0.35) \mathrm{Bb}\end{array}$ & $\begin{array}{c}1.25 \\
(0.12) \mathrm{Aa}\end{array}$ \\
\hline$P\left(\mathrm{mg} \mathrm{kg}^{-1}\right)$ & 1.68 & $\begin{array}{c}1.41 \\
(0.23) \mathrm{Ab}\end{array}$ & $\begin{array}{c}1.17 \\
(0.79) B C\end{array}$ & 1.53 & $\begin{array}{c}1.52 \\
(0.01) \mathrm{Ab}\end{array}$ & $\begin{array}{c}1.45 \\
(0.15) \mathrm{Ab}\end{array}$ & 2.10 & $\begin{array}{c}2.16 \\
(0.15) \mathrm{Aa}\end{array}$ & $\begin{array}{c}2.03 \\
(0.44) \mathrm{Aa}\end{array}$ \\
\hline $\mathrm{K}\left(\mathrm{mg} \mathrm{kg}^{-1}\right)$ & 1.86 & $\begin{array}{c}1.23 \\
(0.37) \mathrm{Ab}\end{array}$ & $\begin{array}{c}0.80 \\
(0.32) \mathrm{Bb}\end{array}$ & 1.55 & $\begin{array}{c}1.05 \\
(0.36) \mathrm{Ab}\end{array}$ & $\begin{array}{c}0.70 \\
(0.09) \mathrm{BC}\end{array}$ & 3.98 & $\begin{array}{c}1.97 \\
(0.34) \mathrm{Aa}\end{array}$ & $\begin{array}{c}1.28 \\
(0.76) \mathrm{Ba}\end{array}$ \\
\hline $\mathrm{Ca}\left(\mathrm{mg} \mathrm{kg}^{-1}\right)$ & 0.61 & $\begin{array}{c}0.51 \\
(0.06) \mathrm{Ab}\end{array}$ & $\begin{array}{c}0.37 \\
(0.09) \mathrm{Bb}\end{array}$ & 4.13 & $\begin{array}{c}3.41 \\
(0.69) \mathrm{Aa}\end{array}$ & $\begin{array}{c}1.92 \\
(0.60) \mathrm{Ba}\end{array}$ & 4.66 & $\begin{array}{c}4.34 \\
(0.66) \mathrm{Aa}\end{array}$ & $\begin{array}{c}2.08 \\
(0.29) \mathrm{Ba}\end{array}$ \\
\hline $\mathrm{Mg}\left(\mathrm{mg} \mathrm{kg}^{-1}\right)$ & 0.51 & $\begin{array}{c}0.40 \\
(0.10) \mathrm{Ac}\end{array}$ & $\begin{array}{c}0.45 \\
(0.10) \mathrm{Ab}\end{array}$ & 0.92 & $\begin{array}{c}0.70 \\
(0.11) \mathrm{Ab}\end{array}$ & $\begin{array}{c}0.70 \\
(0.06) \mathrm{Aa}\end{array}$ & 0.97 & $\begin{array}{c}0.70 \\
(0.27) \mathrm{Aa}\end{array}$ & $\begin{array}{c}0.68 \\
(0.17) \mathrm{Aa}\end{array}$ \\
\hline $\mathrm{Zn}\left(\mathrm{mg} \mathrm{kg}^{-1}\right)$ & 1.43 & $\begin{array}{c}1.36 \\
(0.12) A\end{array}$ & $\begin{array}{c}1.30 \\
(0.17) \mathrm{Ab}\end{array}$ & 1.29 & $\begin{array}{c}1.35 \\
(0.10) \mathrm{Aa}\end{array}$ & $\begin{array}{c}1.36 \\
(0.24) \mathrm{Aa}\end{array}$ & 1.64 & $\begin{array}{c}1.49 \\
(0.05) \mathrm{Aa}\end{array}$ & $\begin{array}{c}1.36 \\
(0.26) \mathrm{Ab}\end{array}$ \\
\hline$C: N$ & 126.49 & $\begin{array}{c}123.68 \\
(30.23) \mathrm{Aa}\end{array}$ & $\begin{array}{c}115.42 \\
(44.88) \mathrm{Aa}\end{array}$ & 64.37 & $\begin{array}{c}40.21 \\
(8,82) \mathrm{Bab}\end{array}$ & $\begin{array}{c}52,66 \\
(9,07) \mathrm{Aab}\end{array}$ & 46,94 & $\begin{array}{c}36,75 \\
(10.00) \mathrm{Ab}\end{array}$ & $\begin{array}{c}39,31 \\
(6,16) \mathrm{Ab}\end{array}$ \\
\hline$C: P$ & 180.84 & $\begin{array}{c}173.94 \\
(48.29) \mathrm{Ab}\end{array}$ & $\begin{array}{c}149.90 \\
(229.89) \mathrm{Aa}\end{array}$ & 371.26 & $\begin{array}{c}477.88 \\
(130.54) \mathrm{Aa}\end{array}$ & $\begin{array}{c}296.30 \\
(40.60) \mathrm{Ba}\end{array}$ & 346.37 & $\begin{array}{c}298.76 \\
(97.22) \mathrm{Ba}\end{array}$ & $\begin{array}{c}307.87 \\
(45.18) \mathrm{Aa}\end{array}$ \\
\hline
\end{tabular}

A. mangium. Compared with reference species, babassu $\mathrm{N}$ and $\mathrm{Ca}$ concentrations in leaves and $\mathrm{N}, \mathrm{Ca}$ and $\mathrm{Mg}$ concentrations in roots were lower at day zero and continued significantly below the concentrations of reference species at both 50 and 138 days (Table 3). Leucaena leucocephala leaves had the highest initial $\mathrm{N}$ concentrations, and also released foliar $\mathrm{N}$ faster than the other species, reaching lower concentrations than babassu leaves at 138 days. The C:P-ratio declined along time for all three species, and was highest in $A$. mangium leaves at 50 days -1.69 times higher than in babassu and 1.47 times higher than in L. leucocephala leaves.

Foliar K concentrations declined 3.5 to 5.8 -fold at 50 days, and only another $18.3 \%$ more at 138 days (means for all three species), pointing to a very rapid and high initial $\mathrm{K}$ release, followed by stabilization at low concentrations. In contrast, $\mathrm{K}$ release was slower in roots, and its concentrations were significantly lower in leaves and roots of all species at 138 days as compared to 50 days. Contrary to $\mathrm{K}$, both foliar $\mathrm{Ca}$ and $\mathrm{Mg}$ concentrations declined slowly between day 50 and 138, though Ca decline was significant in the roots of all three species.

C:N-ratios at day zero in babassu roots were highest (1.96 times higher than in A. mangium and 2.70 times higher than in L. leucocephala) and remained higher throughout the 138 days. In contrast, the babassu roots had the lowest C:P ratio at day zero as compared to $A$. mangium (78.2\% lower) and $L$. leucocephala (54.5\% lower) and remained lower throughout the study period.

\section{DISCUSSION}

Babassu leaves decomposed even slower than those of $A$. mangium, our low-quality refrence species, and had significantly lower macronutrient concentrations (with the interesting exception of higher initial $\mathrm{K}$ concentrations). We can thus conclude that babassu leaves are very low-quality material, with particularly slow decomposition and long residence times. This explains why babassu leaves are widely used as material for roof covers in traditional houses (May et al. 1985), and handicraft manufacture (Campos et al. 2015). Babassu-leaf fibers also have potential for use as reinforcement in polymer biocomposites for varied technical applications (Lemos et al. 2017). Babassu leaf and root litter had significantly lower $\mathrm{N}$ concentrations and higher $\mathrm{C}: \mathrm{N}$-ratios than both legume reference species. Low nutrient contents and slow leaf-litter decomposition may be characteristic of palms in general. In a study in Guatemala, Ewel et al. (1981) reported a $20 \%$ slower leaf decomposition, and low percentages of $\mathrm{N}$, $\mathrm{P}, \mathrm{K}, \mathrm{Ca}$ and $\mathrm{Mg}$ for Attalea cohune, a widespread palmtree in secondary successions in central America, in comparison to other tropical plants. Slow tissue decomposition in litter with low tissue quality is often a consequence of high concentrations of recalcitrant lignin compounds (Seneviratne 2000). The incomplete decomposition of these compounds provides precursors for the formation of soil organic matter (Hättenschwiler and Vitousek 2000). In this context, our results would be consistent with the buildup of soil organic matter in the surroundings of babassu, but also support the view of nutrient impoverishment via the babassu 
decomposition pathway, especially the possibility of increasing $\mathrm{N}$ limitation in babassu-dominated stands.

Contrary to all other nutrient concentrations, K concentrations in babassu leaves were significantly higher in the first 50 days of the study period than in the leaves of both reference species. High initial $\mathrm{K}$ concentrations in babassu leaves suggest there is significant $\mathrm{K}$ leaching from live and decomposing babassu leaves. Babassu palms strongly impact surrounding water and nutrient fluxes, as their crown architecture efficiently captures and channels water flow with high K-concentrations down the leaves and stem (Germer et al. 2012). This could provide a mechanism by which the babassu palm can restore its relatively high $\mathrm{K}$ losses and monopolize $\mathrm{K}$ fluxes in the system.

Ca concentrations declined faster in roots than in leaves, suggesting that belowground organisms specialized in $\mathrm{Ca}$ acquisition could play a distinct role in Ca dynamics (Silver and Miya 2001). Babassu roots had maximum C:N-ratios, which may be a key for soil organic material buildup in babassu-dominated areas. In contrast, babassu-root C:Pratios were significantly lower than in both reference species, pointing to the prevalence of $\mathrm{N}$ limitation over $\mathrm{P}$ limitation, possibly the outcome of the strong association of babassu with arbuscular mycorrhizal fungi (Nobre et al. 2018).

Decomposition (both in terms of biomass and of nutrient depletion) in roots and, partially, in leaves of all three species was faster in old than in young secondary regrowth. Microclimate likely was a key factor (Pandey et al. 2009; Hall et al. 2015), linked with successional shifts in species composition and the increase in species diversity of vegetation and soil and litter decomposer communities (Powers et al. 2009; Schilling et al. 2016). Our data support the idea of an acceleration of litter decomposition and nutrient release along succession.

Babassu leaves decomposed faster in the old babassudominated site, whereas babassu roots did not. The existence of specialized decomposer communities in babassu-dominated stands could provide a possible explanation for this accelerated decomposition dynamics. A related observation was the overall higher variability of biomass loss in the reference species, as opposed to a relatively low variability in babassu leaf- and root-mass loss. This suggests a closer synchronization (or integration) of the native babassu palm with its surrounding decomposer communities than that achieved by the exotic reference species, independently of their tissue-quality.

From a plant's perspective, regulating decomposition could provide an instrument to favorably influence their surroundings, not only via organic matter deposition, but also via subsequent controls of nutrient release. Georeferenced and spatially scaled models show that belowground interactions can alter nutrient absorption within plant 'influence zones' (Hodge 2004). We show that the influence of babassu palms on decomposition depends not only on tissue quality (sensu Tian et al. 1992) and stand age, but might also change according to babassu dominance. Whereas the very slow decomposition of babassu-leaf litter is indicative of soil organic matter buildup, the faster decomposition of babassu roots in babassu-dominated secondary forests suggests the presence of more specialized decomposer communities, a so called home-field advantage effect (HFA, sensu Austin et al. 2014). Furthermore, our data suggest that a HFA likely occurs belowground rather than aboveground, and is stronger in older than in younger regrowth.

Sousa et al. (2016) report that babassu biomass-shares in fine roots in another 3-yr-old fallow site was almost double (25.2\%) of the aboveground biomass shares (14.9\%). Root decomposition represents a significant $\mathrm{C}$ flux in terrestrial ecosystems (Silver and Miya 2001). The high root allocation and accelerated fine-root decomposition of babassu in babassudominated sites, and the capacity of babassu to take advantage of the accelerated root-nutrient release might provide a pathway through which babassu influences its surroundings in its own favor (i.e. a positive 'plant:soil feedback'), possibly via selection of specialized root-decomposer communities.

\section{CONCLUSIONS}

Babassu leaves decomposed very slowly, possibly forming a basis for soil organic matter buildup in babassu-dominated forests. Babassu may also systematically impact belowground plant:soil interactions through the selection of specialized decomposer communities, which accelerate belowground nutrient release. Thus, babassu appears to be able to shape the environment in its surroundings to its favor via distinct decomposition dynamics, providing a possible pathway for its outstanding ecological success in frequently burned and degraded lands throughout Amazonia.

\section{ACKNOWLEDGMENTS}

We gratefully acknowledge financial support by Conselho Nacional de Desenvolvimento Científico e Tecnológico CNPq (CT-Agronegócio \# 39/2007) and provision of a grant to Marcelo Correa Zelarayán by Fundação de Amparo à Pesquisa e ao Desenvolvimento Científico e Tecnológico do Maranhão - FAPEMA.

\section{REFERENCES}

Alvares, C.A.; Stape, J.L.; Sentelhas, P.C.; de Moraes, G.; Leonardo, J.; Sparovek, G. 2013. Köppen's climate classification map for Brazil. Meteorologische Zeitschrift, 22: 711-728.

Austin, A.T.; Vivanco, L.; González-Arzac, A.; Pérez, L.I. 2014. There's no place like home? An exploration of the mechanisms behind plant litter-decomposer affinity in terrestrial ecosystems. New Phytologist, 204: 307-314. 
Ayres, E.; Steltzer, H.; Simmons, B.L.; Simpson, R.T.; Steinweg, J.M.; Wallenstein, M.D.; Mellor, N.; Parton, W.J.; Moore, J.C.; Wall, D.H. 2009. Home-field advantage accelerates leaf litter decomposition in forests. Soil Biology and Biochemistry, 41: 606-610.

Blank, R.R. 2008. Biogeochemistry of plant invasion: A case study with Downy Brome (Bromus tectorum). Invasive Plant Science and Management, 1: 226-238.

Bradford, M.A.; Tordoff, G.M.; Eggers, T.; Jones, T.H.; Newington, J.E. 2002. Microbiota, fauna, and mesh size interactions in litter decomposition. Oikos, 99: 317-323.

Bretz, F.; Hothorn, T.; Westfall, P. 2016. Multiple Comparisons Using $R$. Taylor and Francis, USA, 182p.

Brooks, M.L.; D’antonio, C.M.; Richardson, D.M.; Grace, J.B.; Keeley, J.E.; Ditomaso, J.M.; Hobbs, R.J.; Pellant, M.; Pyke, D. 2004. Effects of invasive alien plants on fire regimes. BioScience, 54: 677-688.

Campos, J.L.A.; Viégas, I.J.M.; Albuquerque, U.P.; Peroni, N.; Araújo, E.L. 2015. Knowledge, use, and management of the Babassu palm (Attalea speciosa Mart. ex Spreng) in the Araripe region (Northeastern Brazil). Economic Botany, 69: 240-250.

Chai, Y.; Yue, M.; Wang, M.; Xu, J.; Liu, X.; Zhang, R.; Wan, P. 2016. Plant functional traits suggest a change in novel ecological strategies for dominant species in the stages of forest succession. Oecologia, 180: 771-783.

Cousineau, D.; Chartier, S. 2010. Outliers detection and treatment: a review. International Journal of Psychological Research, 3: 58-67.

Dubeux Jr., J.C.B.; Muir, J.P.; Apolinário, V.X.O.; Nair, P.K.R.; Lira, M.A.; Sollenberger, L.E. 2017. Tree legumes: an underexploited resource in warm-climate silvopastures. Revista Brasileira de Zootecnia, 46: 689-703.

Ehrenfeld, J.G. 2003. Effects of exotic plant invasions on soil nutrient cycling processes. Ecosystems, 6: 503-523.

Ewel, J.; Berish, C.; Brown, B.; Price, N.; Raich, J. 1981. Slashand-bum impacts on a Costa Rican wet forest site. Ecology, 62: 816-829.

Germer, S.; Zimmermann, A.; Neill, C.; Krusche, A.V.; Elsenbeer, H. 2012. Disproportionate single-species contribution to canopysoil nutrient flux in an Amazonian rainforest. Forest Ecology and Management, 267: 40-49.

Grime, J.P. 1977. Evidence for the existence of three primary strategies in plants and its relevance to ecological and evolutionary theory. The American Naturalist, 111: 1169-1194.

Goebel, M.; Hobbie, S.E.; Bulaj, B.; Zadworny, M.; Archibald, D.D.; Oleksyn, J.; Reich, P.B.; Eissenstat, D.M. 2011. Decomposition of the finest root branching orders: linking belowground dynamics to fine-root function and structure. Ecological Monographs, 81: 89-102.

Hall, S.J.; Silver, W.L.; Timokhin, V.I.; Hammel, K.E. 2015. Lignin decomposition is sustained under fluctuating redox conditions in humid tropical forest soils. Global Change Biology, 21: 28182828.

Hättenschwiler, S.; Vitousek, P.M. 2000. The role of polyphenols in terrestrial ecosystem nutrient cycling. Trends in Ecology and Evolution, 15: 238-243.
Hodge, A. 2004. The plastic plant: root responses to heterogeneous supplies of nutrients. New Phytologist, 162: 9-24.

Hothorn, T.; Bretz, F.; Westfall, P. 2008. Simultaneous inference in general parametric models. Biometrical Journal, 50: 346-363.

IAC. 2001. Análise química para avaliação da fertilidade de solos tropicais. Instituto Agronômico de Campinas, Campinas, 285p.

Jama, B.A.; Nair, P.K.R. 1996. Decomposition-and nitrogenmineralization patterns of Leucaena leucocephala and Cassia siamea mulch under tropical semiarid conditions in Kenya. Plant and Soil, 179: 275-285.

Kourtev, P.S.; Ehrenfeld, J.G.; Häggblom, M. 2003. Experimental analysis of the effect of exotic and native plant species on the structure and function of soil microbial communities. Soil Biology and Biochemistry, 35: 895-905.

Kulmatiski, A.; Beard, K.H.; Stevens, J.R.; Cobbold, S.M. 2008. Plant-soil feedbacks - a meta-analytical review. Ecology Letters, 11: 980-992.

Lemos, A.; Mauss, C.J.; Santana, R.M.C. 2017. Characterization of natural fibers:wood, sugarcane and babassu for use in biocomposites. Cellulose Chemistry and Technology, 51:711-718.

Loehle, C. 1988. Problems with the triangular model for representing plant strategies. Ecology, 69: 284-286.

Maina, G.G.; Brown, J.S.; Gersani, M. 2002. Intra-plant versus Interplant root competition in beans: avoidance, resource matching or tragedy of the commons. Plant Ecology, 160: 235-247.

Marcus, R. 1976. The powers of some tests of the equality of normal means against an ordered alternative. Biometrika, 63: 177-183.

May, P.H.; Anderson, A.B.; Frazão, J.M.F.; Balick, M.J. 1985. Babassu palm in the agroforestry systems in Brazil's Mid-North region. Agroforestry Systems, 3: 275-295.

Mccormack, M.L.; Dickie, I.A.; Eissenstat, D.M.; Fahey, T.J.; Fernandez, C.W.; Guo, D.; Helmisaari, H.S.; Hobbie, E.A.; Iversen, C.M.; Jackson, R.B. 2015. Redefining fine roots improves understanding of below-ground contributions to terrestrial biosphere processes. New Phytologist, 207: 505-518.

Milcu, A.; Manning, P. 2011. All size classes of soil fauna and litter quality control the acceleration of litter decay in its home environment. Oikos, 120: 1366-1370.

Norden, N.; Mesquita, R.C.; Bentos, T.V.; Chazdon, R.L.; Williamson, G.B. 2011. Contrasting community compensatory trends in alternative successional pathways in central Amazonia. Oikos, 120: 143-151.

Nobre, C.P.; Costa, M.G.D.; Goto, B.T.; Gehring, C. 2018. Arbuscular mycorrhizal fungi associated with the babassu palm (Attalea speciosa) in the eastern periphery of Amazonia, Brazil. Acta Amazonica, 48: 321-329.

O'Connell, A.M.; Sankaran, K.V. 1997. Organic matter accretion, decomposition and mineralisation. ACIAR Monograph Series, 43: 443-480.

Pagès, L.; Vercambre, G.; Drouet, J.-L.; Lecompte, F.; Collet, C.; Le Bot, J. 2004. Root Typ: a generic model to depict and analyse the root system architecture. Plant and Soil, 258: 103-119.

Pandey, C.; Srivastava, R.; Singh, R. 2009. Soil nitrogen mineralization and microbial biomass relation, and nitrogen 
conservation in humid-tropics. Soil Science Society of America Journal, 73: 1142-1149.

Powers, J.S.; Montgomery, R.A.; Adair, E.C.; Brearley, F.Q.; DeWalt, S.J.; Castanho, C.T.; et al. 2009. Decomposition in tropical forests: a pan-tropical study of the effects of litter type, litter placement and mesofaunal exclusion across a precipitation gradient. Journal of Ecology, 97: 801-811.

Rahman, M.M.; Moitur, R.M. 2012. Quantitative chemical defense traits, litter decomposition and forest ecosystem functioning. In: Blanco, J.A.; Lo, Y.-H. (Ed.). Forest Ecosystems - More than Just Trees. Intec, Croatia, p.295-314.

Rodrigues, R.C.; Araújo, R.A.; Costa, C.S.; Lima, A.J.; Oliveira, M.E.; Cutrim Jr, J.A.; Santos, F.N.; Araújo, J.S.; Santos, V.M.; Araújo, A.S. 2015. Soil microbial biomass in an agroforestry system of Northeast Brazil. Tropical Grasslands - Forrajes Tropicales, 3: 41-48.

Saad, H.; Charrier-El Bouhtoury, F.; Pizzi, A.; Rode, K.; Charrier, B.; Ayed, N. 2012. Characterization of pomegranate peels tannin extractives. Industrial Crops and Products, 40: 239-246.

Sanginga, N.; Vanlauwe, B.; Danso, S.K.A. Management of biological $\mathrm{N}_{2}$ fixation in alley cropping systems: Estimation and contribution to $\mathrm{N}$ balance. Plant and Soil, 174: 119-141.

Seneviratne, G. 2000. Litter quality and nitrogen release in tropical agriculture: a synthesis. Biology and Fertility of Soils, 31: 60-64.

Schilling, E.M.; Waring, B.G.; Schilling, J.S.; Powers, J.S. 2016. Forest composition modifies litter dynamics and decomposition in regenerating tropical dry forest. Oecologia, 182: 287-297.

Schweiger, A.K.; Schütz, M.; Risch, A.C.; Kneubühler, M.; Haller, R.; Schaepman, M. E. 2017. How to predict plant functional types using imaging spectroscopy: Linking vegetation community traits, plant functional types and spectral response. Methods in Ecology and Evolution, 8: 86-95.

Silver, W.L.; Miya, R.K. 2001. Global patterns in root decomposition: comparisons of climate and litter quality effects. Oecologia, 129: 407-419.
Souto, X.C.; Bolańo, J.C.; González, L.; Reigosa, M. 2001 Allelopathic effects of tree species on some soil microbial populations and herbaceous plants. Biologia Plantarum, 44: 269-275.

Sousa, J.T.R.; Moraes, F.H.R.; Gehring, C. 2016. Root biomass in a shifting cultivation system in the eastern periphery of Amazonia, and contribution of the babassu palm. Agroforestry Systems, 90: 351-360.

Styger, E.; Rakotondramasy, H.M.; Pfeffer, M.J.; Fernandes, E.C.M.; Bates, D.M. 2007. Influence of slash-and-burn farming practices on fallow succession and land degradation in the rainforest region of Madagascar. Agriculture, Ecosystems \& Environment, 119: 257-269.

Teixeira, M.A.; da Graça Carvalho, M. 2007. Regulatory mechanism for biomass renewable energy in Brazil, a case study of the Brazilian Babassu oil extraction industry. Energy, 32: 999-1005.

Tian, G.; Kang, B.; Brussaard, L. 1992. Biological effects of plant residues with contrasting chemical compositions under humid tropical conditions-decomposition and nutrient release. Soil Biology and Biochemistry, 24: 1051-1060.

USDA. 2010. Keys to soil taxonomy. US Department of Agriculture and Natural Resources Conservation, Washington, DC, 338p.

Veen, G.; Freschet, G.T.; Ordonez, A.; Wardle, D.A. 2015. Litter quality and environmental controls of home-field advantage effects on litter decomposition. Oikos, 124: 187-195.

Wang, Z.; Yin, X.; Li, X. 2015. Soil mesofauna effects on litter decomposition in the coniferous forest of the Changbai Mountains, China. Applied Soil Ecology, 92: 64-71.

RECEIVED: $29 / 08 / 2019$

ACCEPTED: $13 / 07 / 2020$

ASSOCIATE EDITOR: Lucia Fuchslueger 